\title{
Implementation of STEAM Method (Science, Technology, Engineering, Arts And Mathematics) for Early Childhood Developing in Kindergarten Mutiara Paradise Pekalongan \\ Ahmad Tabi'in ${ }^{1}$ \\ 1 The State Institute for Islamic Study Pekalongan
}

\begin{abstract}
Suitable education in current development is surely required for every children in order to adapt with changes that occur, this certainly need to be addressed by looking for proper solution used in early childhood learning process, because early childhood education can give great benefit in growth and development for children, it also brings great positive impact for cognitive development, physical, emotional and social in children. Early childhood education is being talked about by applying new STEAM (Science, Technology, Engineering, Arts and Mathematics.) method. This method focuses on collaboration, communication, research, problem solving, and critical thinking ability. Through this approach, children are expected, not only academically intelligent but also socially, it also can stimulate children development optimally. Research aims to find out the extent of implementation STEAM Method for early childhood developing. Method used in the research is qualitative descriptive with classroom teacher, Headmaster, and children in Mutiara Paradise Kindergarten as data source. Techniques of data collection are interview, observation and documentation. Technique of analysis and data collection are reduction, data display and conclusion drawing/verification. The result of the research shows the implementation of STEAM Method is very useful for children development, not only the children able to think critically in solving problem, but also children encounter very good social development.
\end{abstract}

\section{KEY WORDS}

steam method, development, early childhood

\section{CORRESPONDING AUTHOR:}

email: ahmadtabiin6@gmail.com

Manuscript submitted October 21, 2019; accepted December 7, 2019.

Copyright: (C2019 This is an open access article under the terms of the Creative Commons Attribution License, which permits unrestricted use, distribution, and reproduction in any medium, provided the original author and source are credited.
ECRJ (Early Chilhood Research Journal)

ISSN Numbers: Print, 2655-6448; Online, 2655-9315

\section{ADDRESS}

Website: http://journals.ums.ac.id/index.php/ecrj

Address: Pendidikan Guru PAUD

Universitas Muhammadiyah Surakarta

A. Yani Street No. 1, Pabelan, Kartasura, Surakarta, Indonesia Telp. +62-271-717417 ext.

Email: ecrj@ums.ac.id

\section{INTRODUCTION}

In the era of very rapid technological development, today's generation of children grow as smart generation in using digital savvy, which they already know smart devices and internet from birth.
Different challenges will be found kids today. There is a shift in line of work required also a must-have skill by the workforce, when they are grown up. (Alifa, Azzahroh, and Pangestu 2018:85) According to national science foundation showed that in the future, approximately percentage $85 \%$ of job obliging 
its workers to mastering various kinds of skills in science field, technology and mathematics.

Because of that, to make the generation of children and young people today ready to work, need to be given skill briefing STEAM (Science, Technology, Engineering, Arts and Mathematics) also early on balanced nutrition. In this case, the role of school and parents are very important helping to direct the children ready to face the future, which is choosing education for their children, parents must be observant in choosing school which able to help children in growing become more creative, collaborative, communicative and also able to think critically, also helping them to learn become independently (Apriliana et al. 2018). This choosing is important because times have changed which must be followed by all aspects especially educational aspect given to children (Briesch (1997:))

Selection and applying curriculum based on STEAM (Science, Technology, Engineering, Arts and Mathematics) are very important and many benefits for the children, because STEAM curriculum is part of curriculum which developed children creativity focuses on collaboration, creativity, verbal communication as well as non-verbal, research, problem solving and critical thinking. Through this learning approach, children are taught not only smart in academic aspect but also social and emotional aspects (E J kim dkk 2012: 2).

Considering the phenomenon of global development today, certainly children must be guided to be ready for the competition, with children of other nations as well as children from other countries. For that reason, developed countries from the beginning comes with an offer an appropriate education system with needs of the times (Tabi'in 2017a). One of the developed country, America implements international curriculum which is Cambridge Curriculum with active learning method. STEAM Method (Science, Technology, Engineering, Arts and Mathematics) in SA Learning is special designed to develop the way children thinking with $4 \mathrm{C}$ Concepts which are creativity, critical thinking, communication and collaboration (Wijaya, Karmila, and Amalia 2015:86).

Based on the existing phenomena, then the need for power and effort which can change and increase mastery of student's concept which is early childhood can integrate technology and stimulate or sharpening children's creativity so that someday they can survive in facing current development especially ready to face 4.0 era. This effort can be strived for by choosing the precise learning which can integrate science, technology also sharpening early childhood creativity. Characteristic or learning model according to government regulations on education and culture No. 103 Year 2014 about learning on primary education, pre-school education and middle education are a-must interactive learning, interesting, pleasure, challenge, motivate to be active, give enough chance for originator, creativity and independent of existing students (Alexander. 2007). Certainly, learning not only emphasizes on cognitive aspect, but also able to embed positive character on students according to government regulations on education and culture No. 65 year 2013 stated that "Learning 
is process for potential development and character building for every students as the result from synergy between education that takes place at school, family and society..". Urgency of character value inculcation is also in national education goals which is Code Law Number 20 Year 2003 about National Education System stated that function of national education is to develop ability and character shaping, also a civilized nation with dignity in order to enrich the life of a nation, it is intended to develop children potency so that become people who believe and pious toward the one almighty god, noble morals, healthy, knowledgeable, competent, creative, independent and become democracy citizens and also responsible.

But in reality, learning process today still many emphasizes on cognitive aspect only (Rusnayati \& Prima, 2011). The existing learning cannot integrate character value on students so that student character development become less attention eventually students do not have positive characters.

Surely this can adverse impact for children development in the future, because many inappropriate event emerge and done by the children, even in school are like violent done by children to another children, or case happened outside of the school done by students like bullying towards others, and many more (Alifa, Azzahroh, and Pangestu 2018:91).

Science Technology Engineering Art Mathematics (STEAM) Method is an approach in learning process which combines between technology, technique, science mathematics and art in one learning process. Through STEAM approach certainly is expected student can be easier to understand the concept which will deliver and can implement in everyday life also potential dig which exists in themself maximally.

\section{Steam Based Learning}

Learning that has been done in educational system today is still using old system which tend to only force students to memorize and children's achievement measured by how children memorize the given materials. The purpose of the education institution itself is expected the children have good understanding also able to apply the knowledge obtained and can active participate in building environment.

Choosing precise in delivering method or approach is the main key in succeeding to actualize learning outcomes that have been formulated. (Tabi'in 2017b), technique of the presentation was developed by referring to learning outcomes that will be practiced. Simply, the presentation technique which required learning for early childhood is able to motivate or push the children so they will become creative also able to solve problem in daily life aspects by individual or group especially by implementing knowledge also using existing technology as a form of caring respect and contribution for improving the quality of education responsibly (Permatsari (2016: 29)).

Overall, STEAM Method implementation in early childhood learning can motivate children to concept and explore also to develop and use existing APE, hone knowledge ability or cognitive, manipulative and children affective development, also implement simply capilla 
knowledge (2014: 46-51). Therefore, STEAM implementation is suitable used in early childhood learning moreover in learning simply science. STEAM based learning can train children in implementing their knowledge to make design as solving problem form related with the surrounding environment.

STEAM Method is already applied in several developed country such as United States, Japan, Finland, Australia and Singapore in preschool education which is simply early childhood. STEAM is initiative from Natural Science Foundation. The purpose of STEAM implementation in United States is to make the four aspects (Science, Technology, Engineering, Arts and Mathematics) become major career choices for children in the future.

STEAM Method pretty much applied in advanced school learning. This condition is showed from the result of research which claimed that STEAM implementation can increase academic achievement and nonacademic of students. (Wijaya, Karmila, and Amalia 2015b : 85), consequently, the implementation of this method is very precise for students even though in the beginning, to increase the student's interest toward STEAM field become wider. This condition emerges after it is applied in learning, evidently STEAM is able to improve mastering knowledge, apply the knowledge to solve the problem also drive students to create something new. STEAM implementation can be supported by various learning methods. STEAM which is integrative enables various learning method used to support its implementation.

Many modern educations today are introduced with approach patterns like
Science, Technology, Engineering, Arts and Mathematics. All the aspects is systematic way of thinking to be able to understand knowledge and to apply it in daily life, this is suitable for developing early childhood creativity in this era. Amongst variables of STEAM are as follows:

1. Science

Science is systematic thinking process which knowledge passed down based on theory, law, and fact that exist with purpose to find solution of existing problem. The way of thinking is started from making hypothesis or assumption which later proved by science approach. Hypothesis can be proved by using qualitative, quantitative, experiment and also using combination of existing method. Research can prove whether hypothesis is right or not, in this case, then the systematical way of thinking will encourage critical way of thinking to be able to solve daily problems. Every problem has different solving and also requires special approach so that the solving can be more comprehensive in early childhood education certainly require to simply packaging, for example, introducing mixed color, it is already part of simple science context.

2. Technology

In this technology context, it is using technology in education. Technology progress makes easier in learning process, so it will be faster in the knowledge transfer process that was previously difficult to carry out. Every person has different and unique way of learning, so 
that the using of a new technology in certain learning can certainly make it easy every transferring knowledge, which uses learning that can enrich student in experience without have to experience it itself, in this learning process, Audio-Visual is very helpful in learning process for children which is difficult to imagine something abstractly because of visual ways of learning. There are many new technologies which can be used like digital content easier to be shared and to be upgraded so learning process is cheaper and affordable.

3. Engineering

Engineering attribute can be explained as engineering technique used in solving problem in daily life. The engineering process is creative mindset in developing new methods in solving existing problem. The engineering process certainly cannot be separated from thinking process scientifically and new technology applied in its implementation. Popular engineering process in education changes memorize learning process into learning process based on project which is easier to understand and to be experienced itself by the students. The given project is certainly specific with the problem you want to solve and the knowledge to be given.

4. Art

Art is a measure of aesthetics or the value of beauty. In learning process of every human, they will more appreciate something good value in aesthetic. It can be taken an example in learning process using media such as book, video, even other media will certainly more interesting if the visual of the media do not forget the good aesthetic value. In sum, good learning process is started from child interest upon delivered material, so that level of student enthusiasm for learning will always be maintained at high level art, art in children education can be started by singing, finger painting and many more.

5. Mathematic

Mathematics is process of thinking related with basic logic on how everything in this world can be measured, evaluated and help every person in solving daily problems. There are many laws in mathematics, also rules and theories used to approach the logic of a science or problem. Imagine if we live without math logic certainly chaos will occur, so there is effective communication will happen. In other words, math is logical universal language which received by the whole world in communicating a science. Even in arranging music, mathematics is very instrumental in helping arranged, measuring, and evaluating of the music. In sum, mathematics cannot be separated with basic daily logical thinking, mathematical learning process in children is certainly very easy with many ways, one of introducing children to numbers, geometry shapes, and many more.

\section{RESEARCH METHOD}

This is qualitative descriptive research. So writer examines one by one data obtained from Mutiara Paradise Kindergarten 
Pekalongan City later described the data according to what is in the field, however persistent sustainable based on research process that research done in the kindergarten. The subject of the research is directed to related parties and competent in the process of organizing education in Mutiara Paradise Kindergarten Pekalongan City. As for the data source includes, class teacher, educational staff, headmaster, also students in Mutiara Paradise Kindergarten, the research carried out on month of April until September 2018. There are several techniques in collecting data which research do, like observation. Observation carried out regularly and deeply, then semi-structured interview using schedule questioner or interview guide, also documentation. In analyze the data, the writer uses Miles and Huberman Model, meanwhile in analyze data involves data reduction, data display and conclusion.

\section{RESULTS AND DISCUSSION}

\section{Implementation of Steam Method for Early Childhood in Kindergarten Mutiara Paradise}

Early Childhood Education is educational stage where entered before the basic educational level which is a directed coaching effort for children from birth until the age of six. Carried out through providing educational stimuli to help growth and physical and spirit development so the children will have readiness in entering further education, which is hold by formal, non-formal and informal (Ulfah Maulidya 2013).

Early childhood education is an effort to organize education which focuses on laying the foundation towards growth and physical development (delicate and rough motor coordination), intelligent (power of thought, creativity, emotional intelligence, spiritual intelligence), socio-emotional (attitude, behavior, and also religion), language and communication, appropriate with unique and development stages early childhood goes through.

In line with the purpose, it is very exact learning that is in early childhood used STEAM Method. STEAM is stands for Science, Technology, Engineering, Arts, and Mathematics. STEAM is approach developed from STEAM (Science, Technology, Engineering, Arts and Mathematics), in it teaches science, technology, technique, art and mathematics in one single learning activity. (Shin and Han 2011). Learning by using STEAM approach is contextual learning, where student is directed to understand symptoms or phenomena which exist in daily live and close to student themselves. Moreover, STEAM Method is contextual learning approach by gathering several scientific disciplines. The linkages between scientific disciplines, technology, machine, art and mathematics and others disciplines cannot be separated in learning, this can certainly stimulate children development optimally. The expected result from the learning by using STEAM can create effective learning and meaningful for children through integration between knowledge, concept and skill systematically which is combined with the existing game so that student obtain provision of skills from the learning process. Morrison statement in Stothlmann, Moore, \& Roehrig, (2012:29), 
several benefit obtained from STEAM approach are making student to be better in solving problem, become innovator, inventor, logical thinking, independent and mastering literation in technology.

Every discipline in learning and teaching process activity by STEAM approach has several aspects, such as: (1) Science, is disciplines which learns about nature, phenomena happen in it through observation activity and research to obtain fact, concept, principle, and law; (2) Technology means of disciplines application to create a product like stuffs with the purpose to fulfill necessary and human desire; (3) Engineering, is study about how to design and create a technology which is created by application of disciplines and problem solving process; (4) Arts, is subject from the result of the learning which focused on skill process and create product from human creativity in his social life and; (5) Mathematics, is study which learn about the relation between quantity, numbers, form and space (Dahlan : 2016).

STEAM learning implementation pattern for early childhood can be started easily, however it must be adjusted with child growth rates because there is different method between early childhood, elementary and middle school age, if this method is not carefully considered certainly can endanger your own child, because the child is not workable using method which does not match the levels (Connor et al. 2014). In implementing the method, parents or teachers can start implementing STEAM learning pattern by inviting children to play while observing daily activities in the surrounding environment.
Need to be understood that STEAM for early childhood is not only teaching technology but also foster enthusiasm of scientific thinking children ability. Children is directed and also asked to gather data through surrounding environment the report back. For that reason, children study using any concept tends to be easier. In educating early childhood 3 until 6 years old, the most important is we require to build the concept of thinking first, no need to far away to build the concept of thinking, parents and teacher can ask children to the surrounding environment such as rice fields or mountains to help them learning nature. By using minimal costs and improvised equipment, the children can already be a child scientist (Dwi Utami: 2013:142). For the example, when mother brews tea or milk for children, parents can introduce hot and cold concept to children. Or when mother cook vegetables, children can be introduced to variety of vegetables, taught to break it down, determine the size, and cooking order. In Christine (2003: 5) Parents can teach that at home. That is all need to be learned. No need complicated explanation of variety of concepts. Because at early age between 3 until 6 years old indeed they need to know only science thinking learning process.

In STEAM learning implementation, early childhood sometimes not realized asks various questions when they explore natural surroundings, for example, "Why the water can freeze?", "Where is the rain come from?", those questions perhaps considered hard to be answered by early childhood education teacher, despite those questions do not have to be answered by scientific proposition. In fact, 
effective STEAM learning leads the right questions to early childhood to be answered together (WGH 2013: 4).

One of the strategies in making question focuses on "what" not "why". When educator asks question "why", this is show that there is a right answer and children need to test the truth. For example, if educator asks "why the water can freeze?" educator will try to answer those questions with language and children understanding which must to be simplified, because if we textual answer, it will be very heavy to digest by children. However, if educator starts question with "what", educator will start conversation and exploration the right answer. Question "what" focuses on "what is happen", "what do you think my child?" and "what are you doing?" Through focuses on question and what our children already observed and state it, not only helping early childhood in developing communication and also observation skill, but also helping teacher or educator helping children self confidence in giving question which they can answer as an expert (Imaduddin, 2017:955).

\section{Table 1}

Implementation of Steam Method for Early Childhood in Kindergarten Mutiara Paradise

\begin{tabular}{|l|l|}
\hline Science & $\begin{array}{l}\text { The application of science in } \\
\text { question is children ability in } \\
\text { using scientific knowledge } \\
\text { simple, process to understand } \\
\text { nature environment and ability } \\
\text { to participate in taking decision }\end{array}$ \\
\hline
\end{tabular}

\begin{tabular}{|c|c|}
\hline & $\begin{array}{l}\text { to influence it. In this case, } \\
\text { kindergarten already } \\
\text { implemented various things, } \\
\text { for example when outside of } \\
\text { the class in afternoon, the } \\
\text { children overheated because } \\
\text { exposed to the sun and then } \\
\text { asking the children to take } \\
\text { shelter. }\end{array}$ \\
\hline Technology & $\begin{array}{l}\text { Children knowledge in using } \\
\text { new technology simply, having } \\
\text { ability to analyze according to } \\
\text { the level of child development. } \\
\text { For example, related to the use } \\
\text { of cellphone, cellphone is not a } \\
\text { new thing for children } \\
\text { nowadays, almost every child in } \\
\text { kindergarten when asked about } \\
\text { whether they already operate } \\
\text { simply, for example, watching } \\
\text { movie in youtube. }\end{array}$ \\
\hline Engineering & $\begin{array}{l}\text { Children understanding about } \\
\text { hoe technology can be } \\
\text { developed through engineering } \\
\text { or design process using project- } \\
\text { based learning themes by } \\
\text { integrating several different } \\
\text { themes (interdisciplinary), in } \\
\text { this case, simple engineering } \\
\text { what the child does } \\
\text { understands the simply tools or }\end{array}$ \\
\hline
\end{tabular}




\begin{tabular}{|c|c|}
\hline & $\begin{array}{l}\text { engines by seen through the } \\
\text { media image and film. }\end{array}$ \\
\hline Art & $\begin{array}{l}\text { Children understanding about } \\
\text { art, this is already used to do for } \\
\text { example, children singing, } \\
\text { drawing and many more. }\end{array}$ \\
\hline Mathematics & $\begin{array}{l}\text { Collection in analyzing, } \\
\text { reasons, communicating idea } \\
\text { effectively, from how to } \\
\text { behave, formulating, solving } \\
\text { and interpreting the solution to } \\
\text { the simple mathematic } \\
\text { problem in accordance with the } \\
\text { children development stages, } \\
\text { for example, able to distinguish } \\
\text { from each numbers, geometry } \\
\text { shape and many more. }\end{array}$ \\
\hline
\end{tabular}

\section{The Importance of Steam Method for Children Development}

STEAM method emphasizes active learning, stimulate children to solve problems, focus on solution, helping logical and systematic way of thinking, and sharpen critical thinking abilities. STEAM method is important to train critical thinking of children, building logical way of thinking and systematic. Through this method, children will study without realize that they are studying, because is packaged in fun game form for children. Children certainly will be very happy if they are invited to play (William McComas, 2014:102).
This has played big role in preparing children to build competitive character globally and preparing them for career opportunity in technical and creative fields in the future for early childhood.

This STEAM method also very closely related with 21st century learners, because through STEAM method, children will play game which has education value. (Imaduddin 2017) moreover in STEAM method, parents will be taught how to make play activities together with the children at home when vacation come, when the rain is pouring and cannot go anywhere, several activities while on vacation together with family and other situation (WGH 2013:4).

STEAM METHOD makes it possible for us to have their own ideas and make the ideas become real by direct operating. The main purpose of national education is using knowledge to think and to create. STEAM relates knowledge with skill, also teach children for not only having new ideas but also realize this idea in the real world. Means, only knowledge can be manifested into reality which is considered meaningful. B. Elizabeth. (1997:11).

"STEAM method is important for early childhood developing because it emphasizes active learning, stimulates children to solve problem," said Deborah in discussion session 'Prepare the Child's Success from an Early Age by Educative Toys to Stimulate Active Learning' by (Fisher-Price, 2018).

See the excellence of STEAM learning method and understand the important of giving solid basic supplies from an early age. Fisher-Price presents a series of games 'Think 
\& Learn' and 'Laugh \& Learn' which combine STEAM Method and learning system based on technology which is fun and safe for young children.

Furthermore, according to Deborah, children will be trained to focus on solution, build how to think logical and systematic and also sharpen the ability to think critically. This has a big role in preparing children to build competitive character globally and preparing them for career opportunities in technical field and creative in the future.

\section{The Impact of Steam on The Academic Performance of Children in Kindergarten}

STEAM main thought is we must use hand and brain to learn. If children only learn theories in the class, then children will never be able to offset the changing dynamic world. STEAM main feature is learning center from various different subjects, where children can use their hand and brain. Children must practice the knowledge they learn. (Kim et al. 2011)

STEAM is not only learning method, but also way of complex thinking, in the STEAM method education environment, children learn theory and thinking how to use the theory simply. So, when the children grow up and face problems in the real world (for example, environmental pollution around the school which is river pollution because batik waste or global climate change, one of it is frequent rob disaster in Pekalongan City), they understand that to be able to solve the problem then they must use various kinds of knowledge and working together completely; not only relying on one subject of knowledge, for example river that is affected by batik waste, then children know that the effect of river pollution because people throw away their batik waste to the existing rivers, this is certainly wrong because river pollution which creates a pungent.

STEAM change educational system especially on early childhood education system still more focus only on cognitive aspect in the beginning, expected by using this method will change, because STEAM emphasizes the important of direct practice, so student must show determination, creativity, flexibility and their cooperation. (Morrison 2006) learning content consisting of skill and knowledge are thing that education wants to achieve.

\section{Things That can be Done Daily to Sharpen STEAM Ability on Early Childhood in Mutiara Paradise Kindergarten}

1. Encourage Children to Pay Attention to Something

We can invite children to pay attention to things around like changes that occur during the change of seasons, shoots on plants or the way things move because there is wind. Do observation with children and use language related with observation. Observation is the most basic scientific process. By practicing observation, children can see something more detail or scientific and also critical thinking, in this school give children education to observe certain things frequently, for example observe soybean seeds put on the top of cotton simply given water then the seed can grow. This is very good to do because children stimulates to 
think and to ask why the soybean seed can grow.

2. Encourage Children to Describe Things that They See and Do

Children were asked to describe attribute or feature from things that they saw and did in this kindergarten. When children see beetle or butterfly, teacher asks them to describe the detail with color, shape and its size, even though the result is still very simple. Likewise when the children is making or doing something, we can ask them to explain what they being done. This is can elevate vocabularies and child's confident in using STEAM. When studying STEAM used words like predict, experiment and measuring, according to Dahlan.

3. Ask Questions 'What' rather than 'Why'

Teacher frequently asked question which focuses on what can be seen or be done by children in this kindergarten, for example why if you drink you have to sit? Besides this manner is for health, the question is not why. This will make it possible for children to confident in answering the question that they can answer. For example, children is playing bubbles, the question, "What happen with the bubbles" easier to be responded by children rather than this question, "Why bubbles still unite?" According to many early childhood education experts, if we want to expand conversation and learning, do not conceal it by a question that the child cannot answer and do not forget to discuss further children's answers comprehensively.

4. Count by 'One-to-one Correspondence' Technique

It is better for children to be able to do more than counting. Children require to know one-to-one-correspondence technique, that 'one' equal with one object, 'two' equal with two objects, 'three' equal with three objects and so on. Parents can easily develop this skill by asking children, for example collect five garlics for mother to make seasoning two eggs for cake mix or by asking how many existing shopping bags or how many letters on the letter envelope.

5. Invite Children to Imagine the Space Around

Invite children to imagine the space around them. If they see zoo, ask them where they are. When driving to course place for example, ask them to give direction to go there. Or ask children remember the way when we travel with them for example the way to grandma's house. Children perhaps will recognize house from picture that have been taken. From here there is a clear relation between spatial skills and STEAM skills. In this case, children actually can develop complex understanding about world around them of origin with the right guide from their parents or teachers. STEAM experience in early childhood can make it easy for children to learn STEAM later. Parents and teacher do not have to buy 
expensive toys, science tools or work book to fill out. Parents and teacher also do not need to have a degree in the steam method to teach their children. So, teaching children to use STEAM method can be done as early as possible so that it will help capable and confident child in learning something in the child surround environments.

Apart from the above, teacher and parents also can help developing STEAM skills through easy activities to be done in daily life both at home and at school:

1. Ask

2. Facilitate children to cooperate

3. Creative thinking

4. Solving problem

5. Explore

6. Try to answer the problem

7. Looking for unusual new ways

\section{CONCLUSION}

STEAM based learning can train ability and kindergarten children's talents and also can encourage children development aspect. STEAM based learning is also very great to face 21st problems or known as 4.0 industry revolution. Moreover learning in early childhood education which based on STEAM theme expected to be able to produce final output in the form of products and designs made by teacher which later implemented to children which relates to design or simple products. Both of STEAM based learning can be implemented so that expected output should be more complex than the next early childhood education output, several designs that has been conceived require conducted a trial examiner on early childhood education learning. Hereby, design feasibility can be seen and evaluated so that suitable design model is obtained from cognitive aspects and children psychology, aspects of need, culture aspects, understanding aspect and early childhood educational perspective.

\section{REFERENCES}

Alifa, Defara Maulida, Fatimah Azzahroh, and Intan Resti Pangestu. 2018. "Penerapan Metode Stem (Science, Technology, Engineering, Mathematic) Berbasis Proyek untuk Meningkatkan Kreativitas Siswa SMA Kelas XI pada Materi Gas Ideal." In Prosiding SNPS (Seminar Nasional Pendidikan Sains)

Alexander. 2007. Effect Instruction in Creative Problem Solving on Cognition, Creativity, and Satisfaction among Ninth Grade Studenta in an Introduction to World Agricultural Science and Technology Course.Texas Tech University

Apriliana, Mentari Reza, Achmad Ridwan, Tritiyatma Hadinugrahaningsih, and Yuli Rahmawati. 2018. "Pengembangan Soft Skills Peserta Didik Melalui Integrasi Pendekatan Science, Technology, Engineering, Arts, and Mathematics (STEAM) Dalam Pembelajaran Asam Basa." JRPK: Jurnal Riset Pendidikan Kimia $8(2)$

Briesch, Michael S. 1997. Recuperative steam cooled gas turbine method and apparatus, issued June 1997

Chtistine Chaille and Lory Britain, 2013. "The Young Child As Scientist: A Constructivist Approach to Early Childhood Science Education", (Ed) Traci Mueller and Erica 
Tromblay, 3rd edn (Boston: Pearson Education, Inc.

Connor, Andy M., Sangeeta Karmokar, Chris Whittington, and Charles Walker. 2014. "Full STEAM Ahead a Manifesto for Integrating Arts Pedagogics into STEM Education." In 2014 IEEE International Conference on Teaching, Assessment and Learning for Engineering (TALE), 319-326. IEEE.

Dahlan, Ahmad.2017. Pembelajaran Berbasis Science, Technology, Engineering, and Mathematics (STEM). Diunduh tanggal 16 April 2018.

Dokumen diskusi ilmiah 'Persiapkan Kesuksesan Anak Sejak Usia Dini dengan Mainan Edukatif untuk Menstimulasi Pembelajaran Aktif' oleh Fisher-Price, di Mamain, Jakarta Selatan, Rabu (11/4/2018).

E. J Kim and others, 2012. "Development of STEAM Program Math Centered for Middle School Students", Proceedings of the 20th International Conference on Computers in Education, ICCE.

Hurlock, B. Elizabeth. 1997. Perkembangan Anak jilid 1. Jakarta: Erlangga.

Imaduddin ,Muhamad, Mendesain Ulang Pembelajaran Sains Anak Usia Dini Yang Konstuktif Melalui Steam Project-Based Learning Yang Bernuansa Islami, PROCEEDINGS ANCOMS 2017 1st Annual Conference for Muslim Scholars Kopertais Wilayah IV Surabaya.

Jacob Hayward and William McComas, 2014. "STEM: Science, Technology, Engineering, and Mathematics", (Ed) William F.McComas, The Language of Science Education: An Expand Glossary of Key Terms Ana Concepts in Science Teaching and Language (Sense Publishers, 2014).
Kapila, V. \& Iskander, M. 2014. Lessons learned from conducting a K12 project to revitalize achievement by using instrumentation in Science Education. Journal of STEM Education, 15 (1).

Kim, Jeong-A., Byeong-Su Kim, Ji-Hwon Lee, and Jong-Hoon Kim. 2011. "A Study of Teaching-Learning Methods for the ItBased STEAM Education Model with Regards to Developing People of Interdisciplinary Abilities." Journal of Fisheries and Marine Sciences Education 23 (3): 445-460.

Lam, P., Doverspike, D., Zhao, J., Zhe, J. \& Menzemer, C. 2008. An evaluation of a STEM program for middle school students on learning disability related IEPs. Journal of STEM Education, 9 (1\&2).

Makalah Seminar nasional dilaksanakan oleh pemerintah kota Surabaya tanggal 17/10/2019 di Kota Surabaya.

Morrison, J. 2006. "Attributes of STEM Education: The Student, the School, the Classroom." TIES (Teaching Institute for Excellence in STEM) 20.

Permanasari Anna. 2016, STEM Education: Inovasi dalam Pembelajaran Sains, Prosiding dalam seminar pendidikan sains "Peningkatan Kualitas Pembelajaran Sains dan Kompetensi Guru melalui Penelitian \& Pengembangan dalam Menghadapi Tantangan Abad-21" Surakarta, 22 Oktober 2016. Di UMS.

Shin, Young-Joon, and Sun-Kwan Han. 2011. "A Study of the Elementary School Teachers' Perception in STEAM (Science, Technology, Engineering, Arts, Mathematics) Education." Journal of Korean Elementary Science Education 30 (4): 514-523.

Standard Pendidikan Anak Usia Dini (PERMENDIKNAS NO.58 TAHUN 2009) 
Suryadi \& Ulfah, M. (2015). Konsep Dasar Paud. Bandung: PT. Remaja Rosdakarya

Stohlmann, M., Moore, T. J., \& Roehrig, G. H. 2012. Considerations for teaching integrated STEM education. Journal of PreCollege Engineering Education Research Journal of PreCollege Engineering Education ResearchJ-PEER), Journal of PreCollege Engineering Education Research, 2(2), 1-28. http://doi.org/10.5703/1288284314653

Utami Ade Dwi and others. 2013, Pendidikan Anak Usia Dini Jakarta: t.p.

Wijaya, AGUSTA DANANG, NILA Karmila, and MAHMUDAH RIZQI Amalia. 2015a. "Implementasi Pembelajaran Berbasis STEAM (Science, Technology, Engineering, Art, Mathematics) Pada Kurikulum Indonesia." In Proseding Seminar Nasional Fisika Dan Aplikasinya. Tersedia Online: Portal. Phys. Unpad. Ac. Id.

WGH, 9 Story Entertainment and TVOntario. 2013, STEM Sprouts: Science, Technology, Engineering \& Math Teaching Guide, Boston, MA: Boston Children's Museum. 